International Journal for Crime, Justice and Social Democracy

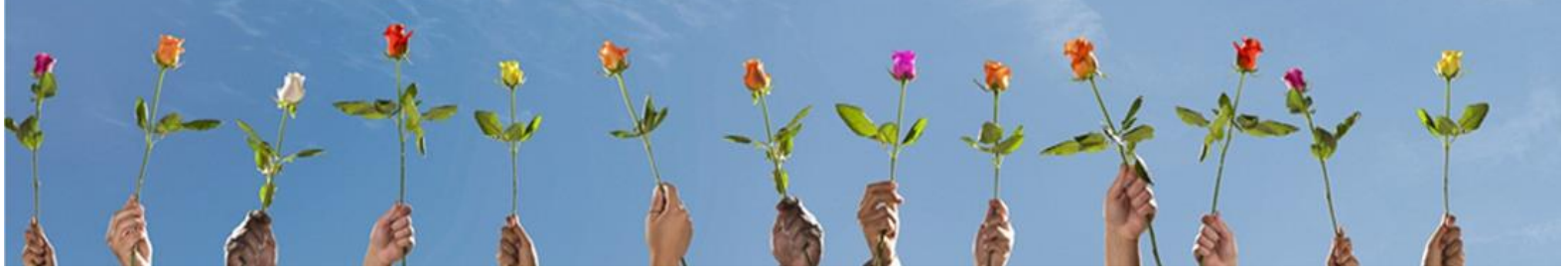

\title{
The Brazilian Federal Supreme Court and the Normalisation of Barbarity $^{1}$
}

\author{
Ana Flauzina 2 \\ Federal University of Bahia, Brazil \\ Thula Pires ${ }^{3}$ \\ Catholic Pontifical University of Rio de Janeiro, Brazil \\ Gisella Lopes Gomes Pinto Ferreira (translator) ${ }^{4}$ \\ Queensland University of Technology, Australia
}

\begin{abstract}
This paper aims to explain the legal-political vocabulary that informs the decisions of the Brazilian Supreme Court on prison issues, giving prominence to the dimensions of race, gender, class and sexuality. In particular, it seeks to show the role of judicial action in the reproduction of black genocide, with significant implications for women, and how the Supreme Court acts as an authority over the barbarism installed in the criminal justice system.
\end{abstract}

\section{Keywords}

Racism; sexism; legal colonialism.

Please cite this article as:

Flauzina A, Pires T and Lopes Gomes Pinto Ferreira G (2021) The Brazilian federal supreme court and the normalisation of barbarity. International Journal for Crime, Justice and Social Democracy 10(4): 102-116. https://doi.org/10.5204/ijcjsd.1806

Except where otherwise noted, content in this journal is licensed under a Creative Commons Attribution 4.0 International Licence. As an open access journal, articles are free to use with proper attribution. ISSN: 2202-8005 


\section{Introduction}

Examining the performance of the bodies of the justice system, specifically the Brazilian Federal Supreme Court (FSC), fundamentally highlights issues that have not changed in the country's historical path. Against a trend focused on exception as an analytical category, there is a black perspective that recognises the continuity of political and social structures as the best way to understand the facts (Hartman 1997). The adoption of this critical stance requires that we explain the premises that guide our view. Here, we designate the right to life and freedom as the metric to guide the perspective of the state's action. Bringing the specific condition of black people to the centre of the debate, we argue that judicial power plays a significant role in expanding the social endorsement for the annihilation of black bodies. These dynamics are informed by gender and sexuality hierarchies that need to be denounced. From this analysis, we use the term genocide in a broad sense, understanding it as a process of suffocating black communities on the most diverse areas of institutional action (Flauzina 2008; Vargas 2010). In this vein, it is necessary to recall the dynamics that determined the election of racism as the cornerstone of the Brazilian State and its legalpolitical institutions.

We learned from Lélia Gonzalez (1988) that Brazil's historical and cultural formation produced a neurosis with racism as its symptom par excellence. The model of European superiority over non-white peoples in the consolidation of the colonial project was forged in the Brazilian experience through a racially hierarchical and stratified organisation model (political, social, economic and cultural). It is not by chance that 'the claim that everyone is equal before the law takes on a clearly formalist dimension in our societies' (Gonzalez 1988: 73). Racism by denial ${ }^{5}$ explains dehumanisation processes perpetuated through the interaction between legal-formal mechanisms of equality established in law and genocidal institutional practices against black bodies. The exception paradigm cannot be sustained because, in moments considered to be of democratic stability, normality has connived with the extermination and the processes of death in life that have been imposed on us. For those who were racially stratified in the zone of nonbeing (Fanon 2008), violence is the norm that supports the exercises of legality and freedom as exclusive attributes of the zone of being. ${ }^{6}$

We align our methodology with the Ladin Amefrican feminism, as proposed by Lélia Gonzalez (1988), by giving centrality to the permanences that coloniality imposes on us through its most diverse dimensions of domination (Collins 2019) and to the possibility of rescuing the common experience that African diaspora bequeathed us (Gonzalez 2018: 335-344). Although we articulate analytical categories such as genocide, coloniality, the zone of being, the zone of non-being and Amefricanity, we are less interested in the work on analytical categories and more interested on lived realities that deserve to be understood along with the complexity in which they were produced (Curiel 2020: 132). Guided by this theoreticalmethodological framework, we understand that despite what has been witnessed in the last thirty years of the Brazilian Constitution of 1988, which maintained the model of coexistence between formal mechanisms of freedom/equality and the massive and multifactorial extermination of black people, the current political context presents new features that must be highlighted. Since President Dilma Rousseff's impeachment in 2016, there have been harmful political programs that escalate the intensity of the ongoing genocidal agenda in the country.

Although there is nothing new in the racism animus, because the annihilations are a constant of the public power in Brazil promoted by all governments, the adoption of a project that celebrates exterminations brings tangible and worrying consequences for black communities. What does the need to institutionalise genocide (through legal-formal dimensions) mean in the Brazilian context? In a country where mothers sleep with the possibility of waking to find their offspring dumped in clandestine/institutional graves/prison cells, the rise of conservatism should not be taken as a minor issue (Rocha 2017). In this context, we understand that it is relevant to take our rightful place and highlight the participation of the legal barricades in complying with this state of affairs. To this end, we propose an Amefrican ${ }^{7}$ reading of the FSC in cases related to the Brazilian prison system, drawing on two decisions in particular. The first example is the Claim of Non-Compliance with a Fundamental Precept 347 from the Federal District, which recognised the unconstitutional state of affairs. Second is the related Habeas Corpus Action 143641 from 
São Paulo (hereafter HC 143641-SP), which deals with manifestations about house arrest for pregnant women, puerperal women, mothers of children and mothers of people with disabilities under the hypotheses of article 318 of the Brazilian Criminal Procedure Code (CPC).

\section{Racism and Sexism in the Brazilian Legal Culture: A Recipe for Death}

The judicial power has historically been able to shield itself from criticism directed at its responsibilities for perpetuating social problems in Brazil. Its image of austerity, cultivated as an institutional ethos, the illusory assumptions of neutrality and the apparent non-association with traditional-political movements make this branch of government less exposed than the executive and legislative branches in terms of social demands and engaging academic analyses. In the past two decades, this trend has been broken owing to greater visibility of the judicial authorities, especially the FSC, after making historical decisions that have increasingly indicated the judiciary as a power to be systematically and critically monitored (Alves 2017; Lauris and Araújo 2017; Zafallon 2018).

The hegemonic discussions about the role of the judiciary as a central political actor, in articulation with the executive and legislative branches, and the role it plays in sustaining the Brazilian State, usually take the Constitution of 1988 as the timeframe for analysis. This constitution supposedly created institutional conditions that were more favourable to judicial activism, which is why this time frame was chosen. However, we understand that by using this timeframe, we lose the opportunity to highlight how the judiciary has historically acted as political power and, consequently, the opportunity to analyse how the justice system has treated citizens of different social classes, gender, race, sexuality and ethnicities in our society. Hence, to understand how the hierarchies of humanity among us are maintained through law, in periods recognised as democratic stability or not, instead of taking the Constitution of 1988 as a timeframe to think the performance of the judiciary, we are interested in understanding the phenomenon from the advent of legal courses in Brazil and the role they play in the formation of the Brazilian State.

Legal courses in Brazil emerged in the context of national independence. Despite the end of colonialism as a concrete regime in 1822, colonial structures, racial, gender, sexual, cultural and economic hierarchies were maintained in a new guise of the liberal capitalism. The creation of legal courses was discussed in the Constituent Assembly of 1823 and sought to meet the demand of the nation-state that was based on conservative liberalism and grounded on slavery. This creation also favoured the formation of an elite, designed to be part of the bureaucratic stratum and to reproduce the European curriculum (Costa 1992: 52). The legal courses established in 1827, initially in São Paulo and Olinda, reproduced the Portuguese academic tradition. The Brazilian law that was constituted throughout the 19th century was guided by constitutional models such as those of the United States (US) independence and the French revolution. In addition, Brazilian law kept many of the Portuguese colonial institutes. However, Brazilian law resulted in the denial of the only radical and antiracist constitutional experience, which was the outcome of the Haitian slave revolution. This experience already pointed out the limits of the US and French constitutional experiences and commitments of the 18th century.

The legal institutes that affirm public freedoms have developed alongside the regimes of slavery, genocide and exploitation of colonised peoples (Queiroz 2017). In this context, the chosen subject of law represented the affirmation of an intended uniformity, forged by the material, subjective and epistemic exclusion of subaltern peoples. The rules that determined the standard to which legal interests were protected were understood as such and protected by law derived from the affirmation of white, male, cisheteronormative, classist, Christian and supremacist values, which do not pertain to natural human diversity (Pires 2018). Thus, it appears that the law and the justice system assumed a central role in the formalisation and maintenance of the structure of coloniality, giving it legitimacy and naturalising its institutes under the sign of neutrality. Within this dynamic, the theory of law and jurisprudence began to consolidate the interests of the hegemonic political agents of the Brazilian State, excluding those whose humanity was denied-not only from the access to justice but the broader normative construction. This repertoire of authoritarian and exclusion bias, the law's inability to produce emancipation for subjects, and the experiences that are not taken into account in the process of determining the legal interests to be 
protected mean that addressing the ineffectiveness/violation of rights cannot be straightforward. In contrast, the law presents itself as the most well-finished form of enunciation of legality as an exclusive attribute of the zone of being (Pires 2018).

In societies founded on colonialism, the demarcation line between the zone of being and the zone of nonbeing establishes the differences between those considered human and those who are robbed of this construction. The colonised, who were racialised as inferior, were confined to a social role of dehumanisation and objectification, which is maintained by permanent violence and silencing. The complexity and internal hierarchies of those who inhabit the zone of being are recognised; they have the social recognition of their humanity, access to rights and material resources, and the social consideration of their subjectivities, identities, epistemologies and spiritualities. Those who inhabit the zone of nonbeing are not only spared from internal hierarchies, but their humanity is denied; consequently, so is their access to rights, material resources and the recognition of their subjectivities, spiritualities, epistemologies and political practices. This world divided between the zones of being, and the zone of non-being is fundamentally sustained by violence. In this vein, the language of the law is essential in endorsing the brutalisation and death processes directed to subaltern contingents-in Brazil, these are demarcated by race and the correlated dimensions of gender, class and sexuality.

The judiciary is a fundamental environment for mobilising the law and plays a key role in sustaining this state of affairs. For this reason, it is necessary to break the deceptive understanding that the judiciary and other bodies of the justice system operate for human rights in a failed attempt to contain violence. By contrast, we understand that judicial control agencies are jointly and severally liable as producers of barbarism, their most dangerous role being the executions directed at black bodies. From this perspective, we cultivate new analytical grounds for questioning what it means to be a black body judged in Brazil. Inspired by Beatriz Nascimento's call (2018) for re-ori-entation (re-orí-entação) ${ }^{8}$ of the debates, we raised some questions: Has the Brazilian justice acted more as a guarantor of the constitutional norms or as an ally of political and social usurpation processes that violate the marginalised population in the country? Are we talking about judges or vigilantes when dealing with institutional agents who work to maintain racial and gender hierarchies? Should summary executions and the culture of incarceration be analysed as isolated police activities or illegal punishments validated by homicidal judges?

What we are questioning here is the fact that institutions are not able to carry out the constitutional mission that justifies their existence. We accept the risk of criticism in the current political climate because we do not intend to continue to be a bargaining chip for political negotiations that generate further democratic stability for the zone of being. The bodies of the justice system need to be held politically accountable for their role in managing black genocide and the (re)production of racism. There is no agreement with arbitrary statements in this perspective, such as those made by Eduardo Bolsonaro ${ }^{9}$ in a lecture during the 2018 election campaign. He said, 'all you need to close the FSC is a police officer from the entry-level and a soldier'.10 There is also no agreement with narratives that endorse measures to weaken the correlation of forces among the constituted powers. This criticism does not aim to contribute to projects focused on the dissolution of institutions as a way of legitimising authoritarianism. On the contrary, it is a call for all those responsible for the (re)production of genocide to be held accountable, each one from their place, to the reality they (re)produce. It is only in this call to accountability that our analyses of FSC decisions must be understood.

\section{How Does the Normalisation of the Unconstitutional State of Affairs Inform the Operation of the Brazilian Justice System?}

Within the scope of the Claim of Non-Compliance with a Fundamental Precept 347 from the Federal District (hereafter ADPF 347-DF), the FSC spoke about the reality of the Brazilian prison system. ${ }^{11}$ For the first time, the FSC recognised the structural dimension of the violence produced by prison conditions. This claim sought, among other specific requests, to recognise the unconstitutional state of affairs. That is, the public recognition that there is an intense and massive violation of prisoners' fundamental rights by action or omission from the public powers of the Federal Government, the states and the Federal District. 
The unconstitutional state of affairs category was consolidated by the Colombian Constitutional Court between 1997 and 2004 and aimed to categorise situations that present at least three elements ${ }^{12}$ : (1) generalised violation of fundamental rights; (2) inertia or repeated and persistent inability of public authorities to change the situation; and (3) demand for coordinated action from multiple authorities to overcome the situation of violation of rights (ADPF 347-DF: 29, 54). Regarding the possibility of applying this category to the Brazilian prison system, Ricardo Lewandowski, Justice of the FSC, said 'this unbearable state has become permanent given the actions and omissions of the public authorities responsible for the Brazilian prison system' (ADPF 347-DF: 29, 179). Justice Celso de Mello reinforced this perspective in his vote:

There is in fact a clear and undisguised 'unconstitutional state of affairs' in Brazil resulting - as denounced by $\mathrm{PSOL}^{13}$-from the failure of the public power to implement effective measures of a structural nature that neutralise the situation of absurd constitutional pathology caused incomprehensibly by the inertia of the State which fails to comply with the Federal Constitution, that violates the Sentence Execution Law and harms the sense of decency of the citizens of this Republic. (ADPF 347-DF: 159, emphasis in original)

According to the vote of Justice-Rapporteur, Marco Aurélio Mello, the application of the mentioned category should represent the following institutional actions:

This Claim involves the problem of the duty of the public power to make improvements in prisons or to build new ones in order to reduce the deficit of prison spaces. It goes further: it deals with the interpretation and application of criminal and procedural laws in order to minimise the prison crisis, implement the efficient use of the budgetary resources of the National Penitentiary Fund-FUNPEN and the duty of development by the Federal Government, states and Federal District of action plans aimed at rationalising the prison system and ending the violation of fundamental rights of prisoners subject to conditions of prison overcrowding, unhealthy accommodation and lack of access to basic rights, such as health, education, healthy eating, work, legal assistance, which are indispensable to a minimal life of dignity and security. (ADPF 347-DF: 15)

Based on the facts presented, the Justice-Rapporteur concluded that in the Brazilian prison system, there is a generalised violation of fundamental rights of prisoners concerning dignity, physical health and psychological integrity' (ADPF 347-DF: 19). Further, he affirmed that prison conditions constitute 'nonobservance by the State of the corresponding legal order' as well as 'degrading, outrageous and unworthy treatment for people who are in custody' (ADPF 347-DF: 19). At first, it can be observed that the court's remarks are in line with the strong condemnation of the conditions of the criminal justice system in the country. However, a closer analysis of the decision allows us to perceive its contradictions.

First, the existence of public institutions that produce degrading, outrageous and unworthy treatments, which should be considered a problem itself, is only viewed as a problem when it entails some type of unwanted outcome by those who benefit from such inequity; that is, the zone of being. Justice Luís Roberto Barroso states in his vote:

The deficiency of the prison system reverses serious and dramatic consequences for the Brazilian society itself, due to the inability of the system to treat these people with the minimum of humanity, which makes the recidivism rates in Brazil among the highest the world. (ADPF 347-DF: 69)

Contrary to what the justice maintains, the central problem is not recidivism, but the inability for people to be recognised and treated in their full humanity outside, and above all, behind bars. The permanence of hierarchies of humanity among us is, per se, what can be most severe and dramatic for the Brazilian society. 
The context of violations that supported the categorisation of the unconstitutional state of affairs arose from the recognition that:

\begin{abstract}
Most of these prisoners are subject to the following conditions: prison overcrowding, torture, homicide, sexual violence, filthy and unhealthy cells, the proliferation of infectious diseases, food unfit for human consumption, lack of drinking water, essential hygiene products, access to legal aid, education, health and work, as well as a wide range of prisons dominated by criminal organisations, insufficient control over the execution of judgements, social, racial, gender and sexual orientation discrimination. (ADPF 347-DF: 23)
\end{abstract}

Additionally, the claim reports situations in which women 'use bread crumbs to contain menstrual flow' due to the absence of basic personal hygiene materials; transgender people being forced into prostitution inside the units; living with precarious hydraulic, sanitary and electrical infrastructures, lack of lighting and ventilation; bathing and sunbathing areas amidst sewers and runoff of urine and faeces; lack of water for shower and hydration; and often rotten food (ADPF 347-DF: 23-24). Given this situation of extreme vulnerability and degradation, the decision states that:

The Government's responsibility is systemic, revealing a broad spectrum of deficiency in State actions. There is the so-called 'structural State failure'. Because the existing laws are not observed, they fail to protect the fundamental rights of prisoners. There is no communication between the Executive and the Legislative, which share the powers to legislate on related matters. The current public policies are unable to revert the unconstitutional situation. By implementing an excessive number of provisional prisons, the Judiciary puts into practice the 'culture of incarceration', which, again, has aggravated prison overcrowding and has not reduced social insecurity in cities and rural areas. (ADPF 347-DF: 28)

Despite recognising that all branches of government and federative units are accountable simultaneously for violations in the context of deprivation of liberty, seven out of the eight requests in the ADPF 347-DF are directed at the participation of the judiciary. They aim to categorise the necessary accountability of the judiciary for the systematic and unconstitutional disrespect towards the maintenance of life, integrity, health, access to education and work while serving a sentence. The judiciary's responsibility was stated in the decision, for example, in the vote of Justice Gilmar Mendes:

The misery in the country's prison system is so notorious that whatever you say, it will be redundant and, of course, shameful for all of us. As I have been highlighted, we within the Judiciary do not have even the excuse of saying that this is the fault of the Administration, because we are administrators of the system. As recently outlined by Justice Celso, we have an enormous responsibility in maintaining this chaotic issue. (ADPF 347-DF: 137)

Two out of the seven requests related directly to the judiciary's performance (requests 'a' and 'c') and refer to the need to provide grounds for decisions determining arrest and to consider the operation of the prison system for the announced measures. Three of the seven requests indicated the need to apply the Sentence Execution Law and the CPC which determine the application of alternative sentences whenever possible and take into account the reality of prison institutions for commuting sentences and other execution measures (requests 'd', 'e', 'f'). The remaining two requests specifically targeted to the judiciary are related to institutional measures already prescribed by law, such as prison joint efforts and detention hearings with the potential to minimise the culture of incarceration (requests ' $b$ ' and ' $g$ '). While the ADPF 347-DF attempted to demonstrate disrespect by the judiciary bodies concerning law enforcement, this argument was used precisely to deny the request in some justice votes. For example, in the final decision, ' $a$ ', 14 ' $c$ ' 15 and ' $\mathrm{d}$ '16 requests were denied-yet not by a unanimous decision, because if the law already obliges what is contained in the request, it would be innocuous for the decision of the FSC determining its enforcement. In light of this opportunity to outline the judiciary's responsibility in shaping the unconstitutional state of affairs, the FSC's option was to grant only two requests. One related to holding detention hearings (the 
request linked to the performance of the judicial branch) and the second pertinent to the release of the accumulated funding from the National Penitentiary Fund (the request regarding the executive branch).

If the state is not able to respect the normative limits imposed for serving a sentence, imprisonment must cease to be used as a mechanism for social intervention. However, the FSC's decision is omitted concerning this finding. It rhetorically circumvents the articulating centre of the requests formulated to adopt a political-legal solution that shields the judiciary from any consequent questioning.

If the state is not able to respect the normative limits imposed for serving a sentence, imprisonment must stop being used as a mechanism for social intervention. However, the FSC's decision is omitted in this regard. It rhetorically circumvents the central arguments of the claim's requests as a way to adopt a political-legal solution that insulates the judiciary from any type of consequent questioning.

In the ADPF 347-DF, the FSC expressly recognises that the legal framework, established to allow the operation of the Brazilian prison system, is being violated structurally by all constituted powers from various federal spheres. In light of this, what does strengthen a system that produces these violations, instead of ending it? As it is typical of the narcissistic pact ${ }^{17}$ of the Brazilian elites, the structural failure of the prison system is explicitly formal, abstract and conceptually declared only to indicate superficial notes of disagreement. The 'failure of the prison system' is repeated, without the violence and unconstitutionality that they reproduce and sustain becoming the responsibility of public bodies. As Lélia Gonzalez (1988) warns us, racism by denial is perpetuated through the coexistence of legal-formal equality institutes and genocidal institutional practices against black bodies. Thus, as there are things that only make sense for the zone of being, the Justice-Rapporteur is able, in the same vote, to declare the unconstitutional state of affairs, keep the prison system operating and say:

Judges and Courts cannot allow the public to lose faith in the 'Judiciary' institution and the criminal justice system. The moral credibility of criminal justice is relevant as a factor of diffuse respect for laws and institutions and for the prevention of taking the law into one's own hands' initiatives. (ADPF 347-DF: 34)

It is the recipe for legal colonialism being applied once again, with one or another contemporary seasoning. Here, it is important to remember that the Brazilian Constitution of 1824 'prohibited the scourge' and maintained slavery. In 2015, the FSC recognised the scourge that occurs in prison units, represented by the unconstitutional state of affairs, without engaging itself to the causes of the systematic violation of rights that take place there in a raw and brutal way.

The normalisation of the unconstitutional state of affairs prevents us from thinking about ineffectiveness, exception, selectivity or moral hypocrisy. We face a reality that institutionalises the lack of access to formal mechanisms of law enforcement for an expressive contingent of the Brazilian population. Despite not being restricted to the prison environment, the effects of this reality are exacerbated in the prison experience. Thus, the affirmation of the existence of the unconstitutional state of affairs does not remove the responsibility for its permanence from the FSC. On the contrary, this recognition formally implies the FSC in its (re)production. Here, it is essential to highlight that in addition to the clear corroboration with the established structures of racism and classism, the way in which the unconstitutional state of affairs was declared reveals a unique vulnerability of women, cis or trans. The unnamed normalisation of masculinity as a standard that informs the prison context (within the units and in the treatment of the procedures for serving sentences by the justice system) is, therefore, a point that needs to be considered.

The FSC's inability to deal, in an imbricated manner, ${ }^{18}$ with the systematic violations that occur in prison units reveals the reproduction of an institutional gaze that reinforces the stigmas about people who experience the horrors of prison and who distance themselves from the model of subject elected by law (e.g., women, non-white people, trans, gays, lesbians or bisexuals, lower-income class, non-Christian or disabled). In a particularly perverse way, attitudes towards gender issues affect the lives of women, especially and overwhelming black women, as we will discuss below. 


\section{Women, Childhood and House Arrest: Reissuing the Free Womb Law?19}

As highlighted, we understand gender implications, within the scope of the FSC's decisions on the Brazilian prison system, based on the dynamics of racism and the category of genocide. In this vein, and following what has already been exposed, we focus on celebrated decisions such as recognising the unconstitutional state of affairs by ADPF 347-DF. Our analysis emphasises how these decisions account for the continuity of the political and social structures of the extermination of the black population in Brazil.

The HC 143641-SP sought to release the pre-trial detention ordered against all pregnant women, puerperal mothers and mothers of children up to 12 years old, or to replace it with house arrest. As the FSC's commitment to freedom is managed by its perception of freedom as an exclusive attribute of the zone of being, the habeas corpus is no longer the heroic remedy 20 to produce freedom. It became a large arena of debate about imprisonment possibilities or, for those who prefer, about the substitution of pretrial detention for house arrest in the cases established by the CPC. As this interpretation was reduced by the FSC, the habeas corpus basically intended to enforce article 318 of CPC. ${ }^{21}$ This habeas corpus was examined in 2018 and sought to enforce a rule that allowed mothers of children up to six years of age to have pre-trial detention substituted by house arrest as of 2011. This possibility was expanded as of 2016 for pregnant women, women with children up to 12 years old and men who are solely responsible for the care of children up to 12 years old. First of all, it is necessary to emphasise that during house arrest, the person remains imprisoned; it is not by chance that it is called prison! Any attempt to attribute emancipation with imprisonment is, at the very least, frivolous.; in the words of the Justice-Rapporteur of this case, Justice Ricardo Lewandowski, the decision does not constitute a violation of the narcissistic pact:

It reminded me that, perhaps, it would be useful to clarify to all those who assist us that we are not releasing these women, these unfortunate women. They will remain in prison, but at home. They will be subject to alternative measures to imprisonment. They will also be in State custody. (HC 143641: 114)

According to article 317 of the CPC, 'House arrest consists in the confinement of the indicted or accused in their residence, only being able to leave with a court authorisation'. Contrary to what the FSC established in the Habeas Corpus Action 142279 from Ceará22 (hereafter HC 142279/CE), we argue that the substitution of pre-trial detention by home arrest for people who meet the criteria of article 318 of the CPC is not an option for judges. Likewise, but for different reasons, we argue that it is also not a choice for people deprived of liberty. Regarding the members of the bench, although the wording of article 318 starts with 'The judge may substitute preventive detention', the only possible interpretation aligned with the article 318-A and with a state that, in prison matters, is recognised as an unconstitutional state of affairs, is that the concession can only depend on the presentation of evidence related to the criteria defined by law. Once the criteria are verified, the concession is mandatory, as well as the application of alternative or precautionary measures other than prison (article 319, CPC). For people deprived of liberty, the substitution of pre-trial detention by home arrest is also not a choice. The cruel and brutal reality of the Brazilian prison system prevents one from considering the choice (as an exercise of taste-selectionpreference) to be arrested in a prison unit or anywhere else (no matter how precarious, whether the fetters remain, or what injustices and other processes of death in life endure). The access to prison systems other than a prison unit is not a choice, but a precarious exercise as perverse as it is to survive (Pires 2015).

When we perceive the effects of such measures on the deepening of racism and cisheteronormative sexism, some aspects of the decision are clear. The first is related to the capacity of such a measure to reinforce the perverse cycle of state violence through the idea of imprisonment as a rule and not as an exception. The stated objective of the measure is to allow mothers to continue the care of their sons and daughters during a crucial stage of their education (from birth to 12 years of age) or because of the need for special care (in the case of dependents with disabilities). Here, a general criticism is given to the established perspective of women in care roles. For the majority of black Brazilian families (primarily constituted by solo mothers), the maintenance of the 'prison', even in the 'household' sphere, places a disproportionate burden on these women in terms of ensuring that they can live with their children. This is because the 
measure is disconnected from the conditions that allow these women to take care of their families' subsistence effectively. Further, it does not implicate the state in the consequences for these family units when these women are submitted to custody. It ignores that the period of imprisonment represents the discontinuity of their places of residence, their work activities, the institutionalisation of their sons and daughters, and the unbearable increase in the family units' expenses (which are usually non-nuclear, according to the bourgeois model). To frame the house arrest as a measure of 'overcoming the culture of incarceration' is a mockery. It is an act of violence that perpetuates and deepens the state's inability to offer the necessary conditions for both decarceration in general, and specifically for families to develop in their fullness.

From a perspective informed by history, as we have endeavoured to consider since the beginning of the article, this measure can be framed a reissue of the Free Womb Law. Here, as in the period of official slavery, it is not an option for people deprived of their freedom to ask whether they prefer to remain in the slave quarters (or in prison units) away from their daughters and sons or enslaved (imprisoned) in other conditions.

The enactment of the Free Womb Law (Rio Branco Law of 28th September 1871) is addressed within the scope of legal colonialism as one of the rules that promoted the transition from official slavery to formal abolition in 1888. How to solve the problem of slavery? Is the solution to end it? No, it has involved promoting new forms of servitude (e.g., the Free Womb Law and the Sexagenarian Law ${ }^{23}$ ) under the guise of a transition to freedom and keeping the rights of the zone of being intact. In the same vein, the FSC affirmed on the headnote of the HC 152932-SP that we need to overcome prison overcrowding. Is it promoting decarceration? No-it is creating new forms of prison management. In this way, despite being separated in time, these measures are, undoubtedly, closely connected. After all, the end of slavery in the 19 th century seemed unreasonable, absurd and frightening ${ }^{24}$ to the eyes of whiteness, just as the struggle for decarceration as a synonym for promoting freedom may seem today.

Just as the decisions that enabled the CPC to allow house arrest in the events of article 318 were celebrated as a progressive measure against the barbarism of the Brazilian prison system, the Free Womb Law was celebrated as the emancipation of an enslaved population (Carneiro 1980). Under the terms of the law, the Brazilian Empire said that the child of a slave woman was born free as of the 28th of September of 1871 when the law was enacted. It was understood that freedom meant that the children would be under the authority of their mothers' masters. After the children reached eight years of age, the masters would have the right to choose: (a) to receive compensation from the state and deliver the child to be institutionalised, or (b) to use the child's services (for free as expected) until they are 21 years old. Consequently, and according to our best understanding, the right of the master of the enslaved woman was transferable by succession and, in the case of the sale of the enslaved woman, the new master subrogated himself to the rights of the predecessor. For this minor (the term used in the law in 1871) to redeem themselves from the burden of servitude, the payment of indemnity to their mother's master was required. Once the indemnity was paid, the state would keep the child institutionalised in its own units, using the child's services, free of charge, until they turned 21 years old. Alternatively, the state would give the child to associations who would exercise the same prerogatives over them.

When we talk about the culture of incarceration, we are talking about racism. The subject matter of ADPF 347-DF is understood by Justice Marco Aurélio as an 'unpopular agenda, involving the rights of a group of people not simply stigmatised, but whose human dignity is considered by many to be lost, before committing the crimes' (ADPF 347-DF: 21). This perspective only makes sense for those who are immune to these processes and intend to maintain the narcissistic pact that sustains this privilege, or for those who imagine that by endorsing this discourse they can approach this place of 'immunity'. Here, it is important to remember that some who commit crimes do not have their humanity questioned, like so many others who are dehumanised, regardless of their conduct being considered illegal by the Brazilian legal system. It is racism that makes this cause unpopular and enables measures intended to promote less degrading conditions for the black population to be institutionally disempowered and intersubjectively supported. 
In 1871 , as in 2018 , the possible advance was to refine the genocidal action of the state through the multifaceted management of imprisonment.

As the refinements of cruelty increase, there are many explicit examples of how cisheteronormative sexism occurs in the performance of the FSC. However, we will present only two hypotheses, which are justified by their force. The first demonstrates the (dis)trust of women's testimonies and the second characterises the complete irrelevance of women in the decision-making process involving their (non) freedom. By assessing the need to comply with the CPC in replacing pre-trial detention with house arrest-a demonstration that children depend on the care of mothers-the Minister-Rapporteur Ricardo Lewandowski initially understood that:

In order to determine the status of children's guardian of the arrested woman, the mother's word must be given credibility. The judge is entitled, without prejudice to complying, from the very beginning, with this determination, to request the preparation of a social report for eventual reanalysis of the benefit. (HC 14364: 57)

In contrast, Justice Dias Toffolli said 'I think, therefore, with all due respect, that giving credibility, purely and simply, to the word of the imprisoned mother to investigate her status as her children guardian is not enough' (HC 143641-SP: 79). Then, he reinforced that 'it is a concern that I really have; that is, the mother's word is not taken as absolutely true and objective. Perhaps, here, there could be a social analysis, a psychological analysis of this situation' (HC 143641-SP:c115-116).

Given the controversy, the Justice-Rapporteur said:

At first, we have to give credibility, just as we do in sexual crimes: The victim's word is very important. If afterwards, it is proved that she is not a guardian, she loses the benefit. However, at first, it needs to be given the benefit of the doubt, in honour of the child's wellbeing. However, I am also open, if Your Honour wants to subtract this paragraph, I am ready to do so, for the benefit of reaching a harmonic solution about this case. (STF, HC 143641-SP: 116)

It was in these terms that two male Justices decided on the value of a woman who, subjected to prison in an environment recognised as an unconstitutional state of affairs, postulates only for the application of the CPC that determines the substitution of pre-trial detention by house arrest.

The second case, even more striking, was expressed in the vote of Justice Edson Fachin. It completely disregards the woman, deprived of her freedom, from the consideration that may allow the application of article 318 of the CPC. In the words of Minister Fachin:

I grant the collective writ of habeas corpus exclusively to give an interpretation under items IV, V and VI of article 318 of the Criminal Procedure Code, in order to recognise, as the only constitutionally adequate interpretation, that conditions the substitution of pre-trial detention by house arrest to the concrete, justified and individualised analysis of the best interest of the child, without the automatic revocation of pre-trial detentions already ordered. (HC 143641SP: 140)

The same Justice who refers to the Kyiv Declaration (which determines that the blatant gender inequality in the establishment of public policy and non-compliance with the minimum rules of the treatment of incarcerated women must be compensated) says that the only interpretation is based on the child's best interest. Therefore, it can be observed that the patterns of gender and race conditions in Brazil end up undermining the declared objectives of decarceration that are supported by the Supreme Court in the declaration of the unconstitutional state of affairs. The Justices' strong alignment with the status quo precludes the more comprehensive application of the rule, violating the rights of thousands of women. 
In pretuguês ${ }^{25}$ (Gonzalez 1988), we recognise that both ADPF 347-DF and the other actions related to the granting of house arrest ${ }^{26}$ have expanded the legal vocabulary for denouncing racism and cisheteronormative sexism within the institutions of the criminal justice system. As per the call for responsibility indicated at the beginning of the article, we intend to outline that the management of this vocabulary by the FSC and by the other bodies of the justice system takes place via a narcissistic pact (Bento 2002). In this vein, what could mean a commitment to freedom and life is covered by the white solipsism (Oyěwùmí 2002) of Brazilian elites that offers a camouflaged shield of legal argument and maintains freedom and access to legality as exclusive attributes of the zone of being. In the context of genocide, freedom is not a product available in the market of the indigent that inhabits the zone of nonbeing, with pain and degradation being the sentences imposed by the whiteness, which are perpetuated in the rituals of the judiciary in Brazil.

\section{Final Considerations}

The way the FSC recognised the unconstitutional state of affairs, and how mothers' rights are dealt with in the context of house arrest, illustrate how the government in Brazil has managed the black genocide. Here, it is crucial to highlight that in the laceration imposed on black communities by this punishment engineering, the most perverse effects are felt by women. Male incarceration disproportionately burdens the lives of women who need to subsist (and ensure the livelihood of many) amidst an environment of economic, family and psychological vulnerability made worse by the imprisonment of their sons, brothers, partners and grandsons. While these effects are real and central to the zone of non-being, they did not even pass through the analysis of the FSC when it expressed the unconstitutional state of affairs.

If male incarceration is devastating for black families, female incarceration, in turn, makes it impossible for us to remain as a family, community and people. For women, cis or trans, who will be subjected to Brazilian prison dungeons, the racism, classism and gender and sexual violence will be aggravated by the deprivation of freedom, in an environment designed to gradually control and kill those whose masculinity has been reduced. The overcrowding, lack of personal hygiene products and means of maintaining health in general, lack of adequate food, lack of job or study offers for the remission of sentences in many prisons and the absence of access to justice-these conditions gain new dimensions when the body that will experience these violations is a female body. Everything precarious or absent in male units becomes precarious/inadequate or insufficient/absent in female or mixed units.

Given this context, the FSC recognises that it is exaggerated and unreasonable to impose pre-trial detentions on poor and vulnerable women, due to excesses in the interpretation and application of the penal and penal procedural law, even in the face of the existence of alternatives of a humanitarian nature that are prescribed in the current legal system. From this perspective, it can only be understood that racism, with its related dimensions of gender and sexuality, is a phenomenon so strong in Brazil that even the top body of the judiciary, the FSC, discusses the need to 'overcome both judicial arbitrariness and the systematic exclusion of rights of disadvantaged groups, typical of legal systems that do not have collective solutions to structural problems ${ }^{27}$. The lack of solutions that produce such illegality/unconstitutionality remains in full operation, and this does not even cause a popular reaction, nor judicial measures to address the problem.

The fragility of institutions in the current political context requires an assertive stance. The harassment by conservative forces on the powers of government is mostly made possible by the historic pact of whiteness to maintain its privileges. In this vein, the affirmation of democracy in Brazil is only possible with the rupture of political agreements that have condemned the black population to the indignity of imprisonment and death. That is why, on the foundation of the black feminism lens that guides us, we denounce the endorsement and active participation of the judiciary in shaping this state of pain and advocate for the end of the barbarism disguised as civility in the intricacies of the law. 
Correspondence: Professor Ana Flauzina, Faculty of Education and Faculty of Law at the Federal University of Bahia, Brazil. Faculdade de Educação da UFBA: Vale do, Av. Reitor Miguel Calmon, s/n - Canela, Salvador - BA, Brazil. Email: anaflauzina@yahoo.com.br

\footnotetext{
1 This article was originally published in Portuguese by the Brazilian journal Revista Direito e Praxis available at https://www.epublicacoes.uerj.br/index.php/revistaceaju/article/view/50270 DOI: 10.1590/2179-8966/2020/50270

2 Ana Flauzina has a PhD in law from the American University Washington College of Law and has held a postdoctoral position at the African and African Diaspora Studies Department from the University of Texas, Austin. She is a Professor at the Faculty of Education and at the Faculty of Law at the Federal University of Bahia, Brazil. Email: anaflauzina@yahoo.com.br ORCID: https://orcid.org/0000-0002-9995-7675.
}

3 Thula Pires is a black woman of axé, Dandara's mother and a ballerina. She has a PhD in constitutional law from the Pontifical Catholic University of Rio de Janeiro. She is a Professor of Law and coordinator of NIREMA (Interdisciplinary Centre for Reflection and Afro-Descendant Memory) at the Pontifical Catholic University of Rio de Janeiro. She is also a visiting professor at the African Gender Institute, University of Cape Town, South Africa. Email: thula@puc-rio.br ORCID: https://orcid.org/0000-0003-2138-5483

${ }^{4}$ Gisella Lopes Gomes Pinto Ferreira is currently a PhD candidate at Faculty of Law at Queensland University of Technology (QUT). She holds an MPhil in Justice from QUT and LLB from Universidade Federal de Minas Gerais, Brazil. Her research explores the prevention of gendered violence in youth cohorts in Brazil and Australia, adopting a southern criminology lens, critical feminist perspective. Email: g2.ferreira@qut.edu.au ORCID: https://orcid.org/0000-0001-5332-3194 This article translation was funded by the QUT Centre for Justice.

${ }^{5}$ Lélia Gonzalez (1988) describes the dynamics of racism in Brazil as racism by denial. To explain this concept, she uses the Freudian category of denial to configure the process by which the individual, although formulating his desires, thoughts or feelings till then repressed, continues to defend himself against them, denying that they belong to him.

${ }^{6}$ Guided by the work of Frantz Fanon (2008) and Sueli Carneiro (2005), we articulate the concepts of the zone of being and zone of non-being to explain the dehumanisation processes that mark the intersubjective and institutional relations in coloniality. We start from the idea that a modern European colonial project, based on slavery, used race to establish an immeasurable separation between humans (representative of the hegemonic self that configures the zone of being) and non-humans (those who make up the zone of non-being, generally referred to as others). The standard of humanity that structures, and is structured by, the very existence of the zone of being is made from the sovereign subject or the hegemonic self (male, white, cis/hetero, Christian, owner and without disabilities). Similarly, and taking into account the colonial gears that forged Améfrica Ladina, 'racism reduces the being ontic dimension, denying its ontological condition, which attributes its human incompleteness' (Carneiro 2005: 27). Although we are talking about incommensurability between the two zones, we understand that there is a relationship between them in that the existence of the zone of non-being is a condition for the existence of the zone of being. The humanity of the zone of being can only be experienced as an exclusive attribute because it is sustained by the permanent violence and the most diverse processes of dehumanisation that are imposed on the zone of nonbeing.

7 The Amefricanity political-cultural category was developed by Lélia Gonzalez (2018: 321-334) to highlight the historical process of the African diaspora in coloniality, reframing the role of the of Amerindian and African culture in the formation of the territory she renamed Améfrica Ladina (in place of Latin America). This process is marked by resistance, acculturation and challenges of the non-place that are presented in the subalternate hierarchies imposed on these inheritances and subjects by the colonial legacy.

${ }^{8}$ With vast production experience in the field of history, we follow Beatriz Nascimento's narrative in the film Ôrí to guide what we are proposing as a re-ori-entation. This documentary was launched in 1989, directed by Raquel Gerber, with a screenplay by Maria Beatriz Nascimento. It rescues the 'transatlantic' relationship between Brazil and the African continent through the performance of black Brazilian movements between 1977 to 1988. The film's title, Ôrí, came from a word with Yoruba origin and an Amefrican perception-it may mean head (physical or interior), the one that guides/references/orientates, brings together intellect/memory/thought, articulating present/past/future or being able to assume the political meaning of black awareness. In Beatriz Nascimento's words, 'ORÍ means the beginning of a new stage of life, a new life, a new encounter. It establishes itself as a rite and only by those who know how to make a head to articulate with itself and complete itself with its past, present, and future; with its origin and with its moment there' (Nascimento 2018: 333).

${ }^{9}$ Eduardo Bolsonaro is a Brazilian federal deputy and the son of the current president, Jair Bolsonaro.

${ }^{10}$ See the report by Rafael Vazquez and Fabio Graner at Valor Econômico on October 21, 2018. https://valor.globo.com/politica/noticia/2018/10/21/para-fechar-o-stf-basta-um-soldado-e-um-cabo-diz-eduardobolsonaro.ghtml

11 Regarding the national prison reality, the following constitutional cases are pending decision or have been decided: RE 580.252-MS, ADI 5.170-DF, RE 641.320-RS, ADI 5.356-MS and RE 592.581-RS. As most of their arguments were revisited during the trial of the preliminary injunction of ADPF 347-DF in 2015, we decided to refer only to parts of the ADPF 347-DF's decision. At the time of submission of this article, February 2020, the final judgment of ADPF 347-DF had not taken place. This is why our content refers to the decision of the preliminary injunction.

12 In this sense, the following decisions of the Constitutional Court of Colombia are highlighted: Sentence SU-559, of November 6, 1997; Sentence T-068, of March 5, 1998; Sentence SU-250, of May 26, 1998; Sentence T-590, of October 20, 1998; Sentence T525, of July 23, 1999; Sentence T-153, of April 28, 1998; Sentence T-025, of January 22, 2004.

13 The Socialism and Freedom Party (PSOL is the abbreviation in Portuguese). 
${ }^{14}$ Request 'a', ADPF 347-DF: '[demand that] judges and courts of the second instance, in decisions determining or maintaining pre-trial detention, provide explicitly reasoning about why they do not apply precautionary measures alternative to prison established in the article 319 of the Code of Criminal Procedure'.

15 Request ' $c$ ', ADPF 347-DF: '[demand that] judges and courts of the second instance expressly consider the chaotic situation of the Brazilian prison system when establishing precautionary measures, sentencing and during the execution of sentences.'

${ }^{16}$ Request 'd', ADPF 347-DF: '[demand that] judges establish, where possible, alternative sentencing to prison, as imprisonment is systematically carried out under conditions much more severe than those admitted by the legal framework'.

17 Guided by Maria Aparecida Bento's work (2002), the narcissistic pact is understood as the tacit agreement between white people to do not recognise themselves as an essential part in the permanence of racial tensions and racism in Brazil.

18 In order to define the concept of imbricação (interweaving) adopted in this work, we use Ochy Curiel's explanation: 'To comprehend the interweaving of oppressions ... is to understand how they have historically crossed our region from colonialism to the contemporary colonialism and how it is expressed in certain subjects that have no privileges of race, class, sex and sexuality, such as black women, indigenous people and rural women of the region' (Curiel 2016: 80). It is a model that allows for understanding of the structural and structuring effects of these categories and how they cross the experience of coloniality (not as identity markers that end within themselves).

${ }^{19}$ By outlining historical landmarks in this article, we are guided by a methodological perspective that is closely related to the adopted theoretical assumptions. Thus, bringing together events such as the Free Womb Law and house arrest for pregnant women and incarcerated mothers is based on the understanding of continuity of assaults carried out against the black population during the historical process. In this vein, Saidiya Hartman, a must-read historian in the black traffic of the Diaspora, works on the notion of an afterlife of slavery as a means to consider the continuous existential subjection of black people, regardless of the acquisition of citizenship and within the framework of genocidal democracies (Hartman 1997). Similarly, the methodology adopted here understands that the space-time distances serve to bring together the events mentioned more so than to separate them, because they denounce the structure of domination. Therefore, the connections established speak more about the perennial pattern of inhumanity and abjection to which black bodies are subjected within the framework of coloniality, than of the political specificities of the contexts in which they are inserted (for further discussion, see Hartman SV 1997; Vargas JHC 2018; Wilderson III FB 2010).

20 The first time we came across the reference that the HC 143641 SP's headnote made to the Brazilian doctrine of habeas corpus and, with it, the need to grant maximum effectiveness of the writ, for a moment we were hopeful that 'maximum effectiveness of the habeas corpus' could mean freedom. Unfortunately, and as is typical of legal colonialism, this expression represented only the procedural extension of the constitutional guarantee to enable its recognition as a class action. Perhaps one day, the Brazilian doctrine of habeas corpus will represent, for Brazil and the world, a jurisdictional experience of commitment to freedom and defense against any and all violations of fundamental rights, as described by Justice Gilmar Mendes in his vote at HC 143641 SP: 'The basic formula allowed us to understand habeas corpus as an instrument of defense in relation to any and all offence perpetrated by the Government to subjective rights'(HC 143641 SP: 89). The same meaning was found on the FSC webpage, referring to the Brazilian doctrine of habeas corpus as 'The theoretical framework led by Ruy Barbosa at the end of the 19th and early 20th centuries, which, due to the lack of constitutional remedies, sought to expand the hypotheses of habeas corpus to safeguard other constitutional rights besides the right to freedom of movement'. Excerpt taken from the section named Legal Vocabulary (Thesaurus).

${ }^{21}$ According to article 318 of the CPC:

The judge may substitute preventive detention for house arrest when the agent is (Wording given by Law No. 12.403 of 2011): I - over 80 (eighty) years (Included by Law No. 12.403, 2011); II - extremely weak due to serious illness (Included by Law No. 12.403, 2011); III - it is essential to the special care of a person under 6 (six) years of age or with a disability (Included by Law No. 12,403, 2011); IV - pregnant woman (Wording given by Law No. 13,257, of 2016); V woman with a child up to 12 (twelve) years old [incomplete age] (Included by Law No. 13.257, 2016); VI - man, if he is solely responsible for the care of the child up to 12 (twelve) years old [incomplete age] (Included by Law No. 13.257, 2016). Sole paragraph. For the substitution, the judge will require adequate proof of the requirements established in this article (Included by Law No. 12.403, of 2011).

Article 318-A:

The preventive detention imposed on pregnant women or who is a mother or guardian of children or persons with disabilities will be replaced by house arrest, provided that (Included by Law no 13.769, of 2018): I - [this person] has not committed a violent crime or a serious threat to individuals (Included by Law No. 13,769, of 2018); II - [this person] has not committed the crime against your child or dependent (Included by Law No. 13.769, of 2018). Article 318-B:

'The substitution mentioned in articles 318 and 318-A may be carried out without prejudice to the concomitant application of alternative measures provided in the article 319 of this Code (Included by Law No. 13.769, of 2018).'

22 In the HC 142279/CE by the Justice-rapporteur Gilmar Mendes, tried in 2017, the FSC understood that the substitution of preventive detention by home arrest in the cases defined in article 318 of the CPC should take place in a strict and diligent manner, checking the peculiarities of each case.

23 This law was enacted in 1885 and determined that all slaves over 60 years old would be freed.

${ }^{24}$ As an example, we use two excerpts from Marcos Queiroz's research (2017) based on the Annals of the Constituent of 1823 through the speech of two deputies. The first that we would like to highlight is from Deputy Constituent Alencar, who, in the discussion on citizenship, said:

I say that the article is in accordance with the principles of universal justice because although it seems that we should make Brazilian citizens to all inhabitants of the territory of Brazil. However, we cannot strictly follow this principle because we have many among us that we cannot include in this rule without offending the supreme law of the salvation of the state. It is this law that inhibits us from making slaves a citizen because in addition of being property 
of others and thus, [making them citizens] we would be offending this [owners'] right if we removed them from the assets of the individuals to which they belong, we would weaken the agriculture, one of the first sources of the nation's wealth , and we would open up a spot of disorders in society by suddenly introducing into it a bunch of men who came out of captivity and could hardly be guided by principles of well-understood freedom (Queiroz 2017: 159).

The second excerpt is from Deputy Costa Barros, recommending to the government the rapid extinction of the quilombo called Guandú - a request approved two days later by the other members of the Constituent Assembly:

Mr. President, the time for requests has come and I have to make one so that the Assembly can take it into account: there is a general outcry throughout this city for the number of fugitive slaves ... I do not know a single house among my friends that does not have fugitive slaves: and I am aware that there are quilombos of 100, and even 1000 fugitive slaves: this is a force that is increasing close by the city, and that can be problematic: it is necessary to take this into account ... These collusion [groups] are increasing every day and the consequences that may result from it are not taken into account. Therefore, I ask that the government to promptly strive to extinguish these quilombos ... I request the government to send such a force, that will not be mistreated again, and achieve the total extinction of those gathering'. (Queiroz 2017: 154)

25 Gonzalez called pretuguês ('blackoguese') the Africanisation mark on the Portuguese language spoken in Brazil.

${ }^{26}$ On this topic, we focused more specifically on the HC 143641-SP, and made specific references to other relevant decisions, such as the HC 152932-SP and the HC 142279-CE, all of them judged by the Supreme Federal Court.

27 Headnote from HC 143641-SP, item XIII.

\section{References}

Alves D (2017) Rés negras, juízes brancos: Uma análise da interseccionalidade de gênero, raça e classe na produção da punição em uma prisão paulistana. Revista CS 27: 97-120. https://doi.org/10.18046/recs.i21.2218

Bento MAS (2002) Branqueamento e branquitude no Brasil. In Carone I and Bento MAS (eds) Psicologia Social do Racismo: Estudos Sobre Branquitude e Branqueamento no Brasil: 25-58. Petrópolis: Vozes.

Carneiro É (1980) A Lei do Ventre-livre. Afro-Ásia 13: 13-25.

Carneiro AS (2005) A construção do outro como não-ser como fundamento do ser. PhD Thesis, University of São Paulo, Brazil.

Collins PH (2019) Pensamento Feminista Negro: Conhecimento, Consciência e a Política do Empoderamento. São Paulo: Boitempo Editorial.

Costa AB (1992) Ensino Jurídico: Disciplina e violência simbólica. Mphil Thesis, Federal University of Santa Catarina, Brazil.

Curiel 0 (2016) De las identidades a las imbricación de las opresiones: Desde la experiencia. In Flauzina A and Pires T (eds) Encrespando: Anais do I Seminário Internacional: Refletindo a Década Internacional dos Afrodescentendes (United Nations, 2015-2024): 75-89. Brasília: Brado Negro.

Curiel O (2020) Construindo metodologias feministas a partir do feminismo decolonial. In Hollanda HBd (ed.) Pensamento Feminista Hoje: Perspectivas Decoloniais: 120-138. Rio de Janeiro: Bazar do Tempo.

Fanon F (2008). Pele negra, máscaras brancas. Translated by Renato da Silveira. Salvador: EDUFBA.

Flauzina ALP (2008) Corpo Negro Caído no Chão: O Sistema Penal e o Projeto Genocida do Estado Brasileiro. Rio de Janeiro: Contraponto.

Gonzalez L (2018) Primavera para as Rosas Negras: Lélia Gonzalez em Primeira Pessoa. União dos Coletivos PanAfricanistas (UCPA): Diáspora Africana.

Gonzalez L (1988) A categoria político-cultural de amefricanidade. Tempo Brasileiro 92 (93): 69-82.

Hartman SV (1997) Scenes of subjection: Terror, slavery, and self-making in nineteenth-century America. New York: Oxford University Press on Demand.

Lauris É and Araújo S (2017) Reforma global da justiça, pluriversalismo e legalidade subalterna: Reflexões teóricas e empíricas a partir de uma ecologia de justiças no Brasil, em Moçambique e em Portugal. A Revista Cronos 16: $87-113$.

Nascimento B (2018) Beatriz Nascimento, Quilombola e Intelectual: Possibilidade nos Dias da Destruição. Diáspora Africana: Editora Filhos da África.

Oyěwùmí $O$ (2002) Conceptualising gender: The Eurocentric foundations of feminist concepts and the challenge of African epistemologies. Jenda: A Journal of Culture and African Women Studies 2(1): 1-9.

Pires T (2018) Racializando o debate sobre direitos humanos. SUR-Revista Internacional de Direitos Humanos 15 (28): 65-75.

Pires T (2015) Do ferro quente ao monitoramento eletrônico: Controle, desrespeito e expropriação de corpos negros pelo Estado Brasileiro. In Flauzina ALP and Freitas FdS (eds) Discursos Negros: Legislação Penal, Política Criminal e Racismo: 44-82. Brasília: Brado Negro. 
Queiroz MVL (2017) Constitucionalismo Brasileiro e o Atlântico Negro: A experiência constitucional de 1823 diante da Revolução Haitiana. MPhil Thesis, University of Brasília, Brazil.

Rocha L (2017) Morte íntima: A gramática do genocídio antinegro na Baixada Fluminense. In Flauzina A and Vargas J (eds) Motim: Os Horizontes do Genocídio Antinegro na Diáspora. Brasília: Brado Negro.

Vargas JHC (2010) A Diáspora Negra como Genocídio. Revista da ABPN 2: 31-56.

Vargas JHC (2018) The denial of antiblackness: Multiracial redemption and black suffering. Minneapolis: University of Minnesota Press.

Wilderson III FB (2010) Red, white \& black: Cinema and the structure of US antagonisms. Durham: Duke University Press.

Zaffalon L (2018) A política da justiça: blindar as elites, criminalizar os pobres. São Paulo: Hucitec Editora.

\section{Legislation cited}

Código de Processo Penal 1941 [Criminal Procedure Code 1941] (Brasil) Decree-Law No. 3689, 3 October 1941. http://www.planalto.gov.br/ccivil 03/decreto-lei/del3689.htm

Institui a Lei de Execução Penal 1984 [Sentence Execution Law 1984] (Brasil) Law No. 7210, 11 July 1984. http://www.planalto.gov.br/ccivil 03/leis/17210.htm

\section{Cases cited}

Federal Supreme Court ADPF 347-DF. Justice-Rapporteur Marco Aurélio.

Federal Supreme Court HC 143641-SP. Justice-Rapporteur Ricardo Lewandowski.

Federal Supreme Court HC 152932-SP. Justice-Rapporteur Ricardo Lewandowski.

Federal Supreme Court HC 142279-CE. Justice-Rapporteur Gilmar Mendes. 